\title{
EFFECT OF PHYSICAL ACTIVITY LEVEL ON THE COURSE OF PNEUMONIA CAUSED BY COVID-19
}

Samoylov AS, Udalov YuD, Nazaryan SE, Naikina AV, Pustovoit VI

Burnasyan Federal Medical Biophysical Center of Federal Medical Biological Agency, Moscow, Russia

\begin{abstract}
Data from medical records of 144 COVID-19 patients who had completed inpatient treatment were analyzed, as well as the results of the subsequent survey using a modified questionnaire. The relationship between physical activity level, performance, quality of life (prior to infection and after treatment), age, therapeutic exercises execution rate while staying in the hospital, stool problems, high blood pressure episodes after treatment, and the course of the disease was evaluated. The patients were divided into a control and experimental group in accordance with the the initial subjective level of performance. The moderate form of the disease prevailed (69.44\%). The mild form was typical for younger patients, the patients over 50 years of age made up $62.49 \%$ of the total number of severe cases. Severe patients reported lower quality of life and performance prior to the disease compared to those with moderate and mild course of the infection. The patients (mild and moderate cases) with more active initial lifestyle and higher initial performance who practiced therapeutic exercises while staying in the hospital had a more favorable course of the disease (reduced length of stay in a hospital, fast recovery of performance, reduced number of CT scans). The higher initial physical activity level contributed to milder course of the infection. It is necessary to raise public awareness, especially among the elderly, about the regular physical activity benefits and the correlation between physical activity level and the course of the disease, as well as to introduce exercise therapy at all treatment stages.
\end{abstract}

Keywords: physical activity, COVID-19, coronavirus disease, elderly people, sedentary lifestyle, physical exercises

Received: 17.06.2020 Accepted: 12.07.2020 Published online: 27.07.2020

DOI: $10.47183 /$ mes.2020.004

\section{ВЛИЯНИЕ УРОВНЯ ФИЗИЧЕСКОЙ АКТИВНОСТИ НА ТЕЧЕНИЕ ПНЕВМОНИИ, ВЫЗВАННОЙ COVID-19}

\author{
А. С. Самойлов, Ю. Д. Удалов, С. Е. Назарян, А. В. Найкина, В. И. Пустовойт
}

Федеральный медицинский биофизический центр имени А. И. Бурназяна ФМБА России, Москва, Россия

\begin{abstract}
Проведен анализ данных медицинской документации 144 пациентов с COVID-19, завершивших стационарное лечение, а также последующее анкетирование с помощью модифицированного опросника. Оценивались связь уровня физической активности, работоспособность, а также качество жизни (до заболевания и после окончания лечения), возраст, частота выполнения лечебной физкультуры на госпитальном этапе, наличие нарушений стула, эпизодов повышения артериального давления после окончания лечения с течением заболевания. Пациенты были разделены на контрольную и экспериментальную группу в зависимости от исходного субъективного уровня работоспособности. Преобладала среднетяжелая форма (69,44\%). Легкая форма характерна для более молодых пациентов, пациенты старше 50 лет составляют 62,49\% от общего числа случаев тяжелого течения. Пациенты, перенесшие тяжелую форму заболевания отмечали качество жизни и работоспособность до болезни на более низком уровне, в отличие от перенесших среднюю и легкую форму. Изначально ведущие более активный образ жизни пациенты с исходно более высокой работоспособностью и качеством жизни, выполнявшие лечебную физкультуру на госпитальном этапе (при легкой и среднетяжелой форме) имеют более благоприятное течение заболевания (сокращение сроков госпитализации, скорейшее восстановление работоспособности, уменьшение количества проведенных компьютерных томографий органов грудной клетки). Исходная более высокая физическая активность способствует более благоприятному течению заболевания. Необходимо повышать осведомленность населения о пользе регулярной физической активности и ее связи с течением болезни, особенно среди пожилых людей, а также внедрять методики лечебной физкультуры на всех этапах лечения.
\end{abstract}

Ключевые слова: физическая активность, COVID-19, коронавирусная инфекция, пожилые люди, гиподинамия, лечебная физкультура

Статья получена: 17.06.2020 Статья принята к печати: 12.07.2020 Опубликована онлайн: 27.07.2020

DOI: $10.47183 /$ mes.2020.004

At the current stage of community development the increase in life expectancy is observed. It should be noted that the proportion of people aged over 60 in the general population grows faster than the total population. Thus, a continuous trend towards ageing of the world's population is reported. This led to the World Health Organization introducing the following new age classification in 2018: people aged 60-75 were considered ageing and elderly, people aged 75-90 were considered old, and people aged over 90 were considered centenarians.

At the same time, urbanization, continuous development of new technologies, improvements in transport are accompanied by the sedentary lifestyle rate growth, which negatively affects both people's physical health and economic development contributing to increased incidence of somatic pathologies and, consequently, to the public health costs increase [1, 12].

It has been revealed that regular physical exercises contribute to prevention and improvement of most common noncommunicable diseases being the chief causes of death in people all over the world, and also reduce the risk of falls and injuries from falls, which is extremely important for elderly people [2, 3]. According to the $\mathrm{WHO}$, insufficient physical activity is one of the four top risk factors of noncommunicable diseases together with tobacco smoking, unhealthy diet and alcohol consumption [2]. Consequently, in 2018 the WHO issued the "Global Action Plan on Physical Activity 2018-2030: More Active People for a Healthier World", which underlined the importance of regular physical exercises for modern people. Also in 2018, in Moscow (and then in a number of regions) the extremely successful and popular Moscow Longevity project was launched aimed at increasing the older people's vitality and improving their quality of life.

In March 2020, during the American Heart Association EPI | LIFESTYLE 2020 Scientific Sessions it was reported that elderly people could live healthier lives by increasing their physical activity [4]. It should also be noted that elderly people have lower level of immunity, and physical exercises may help to improve the stress tolerance and activate the immune system.

Given the mostly airborne transmission of COVID-19 and high disease susceptibility and severity in people aged 65 and over, first in Moscow (since March 26) and then in other regions of Russian Federation the self-isolation regime was announced for people over 65 and people with some somatic pathologies aimed at prevention of the novel infection spread (order from Moscow Mayor №26-YM dated March 23, 2020). 
Under prevailing conditions regardless of their initial physical activity experience people aged 65 and over were forced to change their lifestyle to hypodynamic for a long period. The typical for Russian community sedentary lifestyle of elderly people became more complicated due to small living space (at the place of residence of self-isolation).

Under such circumstances the value of regular physical exercises in people aged 65 and over, both during self-isolation and during normal live, becomes not only the medical challenge (disease prevention) but also the social medicine objective [5, 6, 11]

The importance of care and health promotion in at-risk population is emphasized by the correlation revealed between high morbidity, mortality and insufficient level of vitamin D most typical for elderly people [7].

According to the $\mathrm{WHO}$ recommendations, elderly people should do at least 150 min of physical activity throughout the week (just over 20 min a day) [8]. However, at least the routine physical activity should be maintained in the changed life circumstances. Explaining the more active lifestyle benefits should be used to achieve at least the minimum activity even in elderly patients with sedentary lifestyle, provided their initial condition allows them to handle the load [9].

To cope with the current situation, in April 2020 the infectious hospital for patients with COVID-19 was established on the basis of Burnasyan Federal Medical Biophysical Center of Federal Medical Biological Agency. Patients with suspected and confirmed COVID-19 were admitted to hospital.

The study was aimed to evaluate the patients with novel coronavirus infection completed inpatient treatment cases in order to reveal the relationship between the initial physical activity level, patient's age, practicing therapeutic exercises therapy while staying in the hospital, and the course of the disease.

\section{METHODS}

Data from medical records of 144 COVID-19 patients who had completed inpatient treatment in the infectious hospital for patients with COVID-19 in April-May 2020 (discharged with improvement). All patients were diagnosed in accordance to ICD-10 U07.1 (coronavirus infection caused by COVID-19, virus identified) or U07.2 (coronavirus infection caused by COVID-19, virus not identified) [10]. During the impatient treatment at different stages of care provision the patients were introduced to various methods of breathing exercises and exercise therapy used to reduce the length of stain in a hospital and improve the disease prognosis. The patient received a discharge summary with a complex of exercises to be done during self-isolation (within 14 days after the impatient treatment completion). Patients with mild, moderate and severe infection were divided into experimental and control groups according to initial (prior to the disease) subjective performance level, quality of life and physical activity. The listed parameters were evaluated using the modified questionnaire after the inpatient treatment completion in order to assess the physical activity level, quality of life, physical performance, everyday skills prior to infection, and the degree of those parameters decrease after discharge. It was specified, if the patients practiced therapeutic of breathing exercises while staying in the hospital and at home after discharge, or not, and if they experienced high blood pressure episodes and stool problems after discharge from hospital. The patients with pronounced cognitive impairment and severe condition due to comorbidities were excluded from analysis, since it was difficult to acquire data on that category of patients (uncooperativeness, inability to answer questions). The study results were processed using the Microsoft Excel
2016 application. The average values were calculated as the arithmetic mean

\section{RESULTS}

The analysis of data from medical records revealed the following: in most patients admitted to infectious unit (69.44\%) the course of novel coronavirus infection was moderate, in $13.89 \%$ of patients in was mild, and in $16.67 \%$ of patients it was severe.

Analysis of the sex/age composition revealed that women predominated only among patients with moderate infection (54.00\%). The proportions of men and women among patients with mild and severe infection were equal (50.00\%).

Analysis of the proportion of confirmed and not confirmed COVID-19 revealed that patients with confirmed diagnosis prevailed among patients with mild and moderate course of the disease (65.00 and $92.00 \%$ respectively). The highest proportion $(54.17 \%)$ of patients with the "virus not identified" status (negative SARS CoV-2 PCR test result) was observed in the group with severe disease compared to other groups. However, coronavirus infection (COVID-19) was diagnosed according to combined clinical and anamnestic data, epidemiological data and the results of instrumental and laboratory tests. Some of these patients were transferred from other hospitals or received etiotropic therapy on an out-patient basis. The virus could be eliminated under the impact of antiviral therapy.

Analysis of the age composition showed that younger patients had milder COVID-19. Thus, 55.00\% of patients with mild infection were under 40 years of age $(45.45 \%$ of patients were less than 30 years of age).

Most patients with moderate course of the infection (69.00\%) were aged 40-79.

Analysis of the age composition in patients who had overcome severe coronavirus infection revealed a clear trend towards the increase of the older patients' proportion. There were no young patients (aged 20-29) in that group. The highest proportion of severe cases (25.00\%) was in the age group 40-49, next came the older age groups. In general, patients over 50 made up $62.49 \%$ of the total number of severe cases.

The patients spent 6-29 days in the hospital (an average of 14 days).

The diagnosis was verified inter alia using the computed tomography (CT). The number of scans varied from 1 to 6 (an average of 2.97 per individual).

Most patients had comorbidities (65.28\%), generally cardiovascular and endocrine disorders (hypertension, diabetes mellitus, obesity, heart rhythm disturbances).

Most patients did therapeutic and breathing exercises while staying in the hospital (75.00\%). However, the recommended therapeutic exercises during self-isolation (within 14 days after discharge) were practiced by insignificantly higher proportion of patients (77.77\%).

The patients who had overcome the severe form of the disease reported the lower quality of life prior to infection (an average of 8.62 points out of 10) compared to patients with moderate (an average of 9.20 points out of 10 ), and mild forms of the disease (9.10 points out of 10). The initial performance was better in patients who had overcome the mild infection (9.65 - mild course, 9.15 - moderate course, 8.40 - severe course).

The analysis (experimental group) included patients with higher initial subjective level of performance, quality of life and physical activity, $50.00 \%$ in each group according to the severity of the disease. 
Thus, the experimental group comprised:

1. Mild course: 10 people;

2. Moderate course: 50 people;

3. Severe course: 12 people.

Consequently, the control group included the same number of patients (10 - mild course, 50 - moderate course, 12 - severe course). The stool problems and the level of blood pressure control (episodes of high blood pressure) after discharge were evaluated as possible indirect signs of insufficient physical activity (-).

The largest group of patients with moderate infection had the following structure according to the types of comorbidities: $59.00 \%$ of patients had hypertension (stages 1-3), $18.00 \%$ of patients had excess body weight or obesity, $16.00 \%$ had type 2 diabetes mellitus, and $12.00 \%$ had heart rhythm problems (in the history or recorded after admission to hospital). Patients of experimental and control group were comparable according to comorbidities' types.

\section{DISCUSSION}

Thus, patients with mild form of the disease, as well as patients with moderate and severe forms having higher initial performance and quality of life prior to COVID-19 infection required fewer bed-days in the hospital (by 2.01 bed-days in patients with mild and moderate course, by 2.70 bed-days in severe patients). Recovering from the disease, the experimental group patients with mild and moderate infection also rated their quality of life and performance higher compared to the control group patients.

The experimental group patients with mild infection reported no high blood pressure episodes (vs. $50.00 \%$ of control group patients) and stool problems (vs. $25.00 \%$ of control group patients). The high initial level of physical activity was confirmed by the majority of patients doing therapeutic exercises for deterioration of condition and disease progression prevention (50.00\% of experimental group vs. $25.00 \%$ of control group).

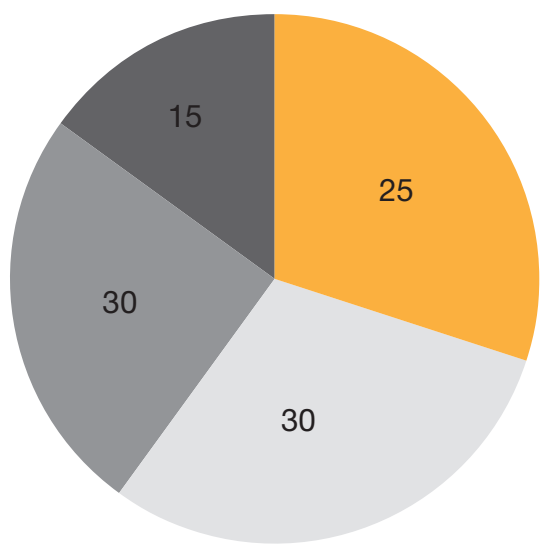

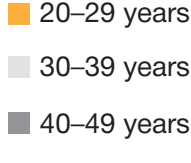

60-69 years

Fig. 1. Age structure of the group with mild form of the disease, $\%$

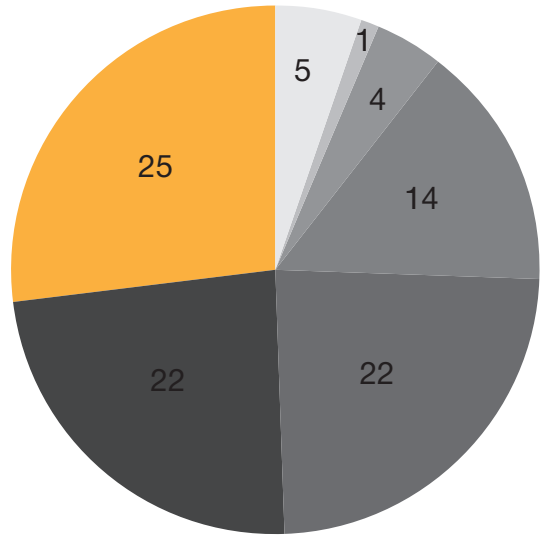

20-29 years

30-39 years

40-49 years

50-59 years

60-69 years

70-79 years

$80+$ years

Fig. 2. Age structure of the group with moderate form of the disease, $\%$

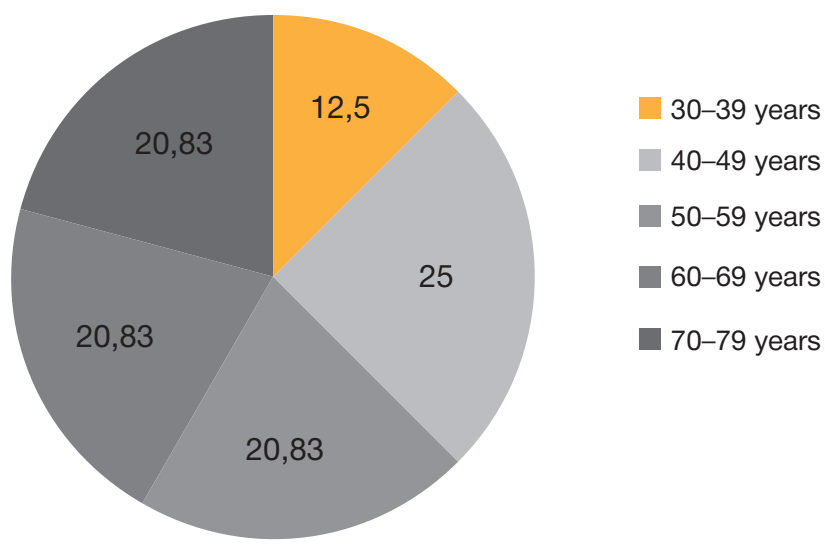

Fig. 3. Age structure of the group with severe form of the disease, \% 
That could contribute to the required total bed-days reducing and milder course of infection.

Therapeutic exercises, both in the hospital and after the inpatient treatment completion, were most actively practiced by patients with moderate course of the disease. Thus, $94.00 \%$ of experimental group patients did therapeutic exercises both while staying in the hospital and at home. In the control group, only $57.00 \%$ of patients did therapeutic exercises during the inpatient treatment (and $66.00 \%$ of patients practiced therapeutic exercises after the treatment completion). The use of exercise therapy methods correlated with reduced length of

Table 1. Patient characteristics: mild form of the disease $(n=20)$ stay in a hospital, higher quality of life and performance rating, both initially and after discharge from hospital.

Despite the high blood pressure or hypertension diagnosed in $59.00 \%$ of that group, only $7.00 \%$ of patients from experimental group reported episodes of high blood pressure after discharge (vs. 17.00\% of control group), and only $5.00 \%$ reported stool problems (vs. 13.00\% of control group).

In patients with severe infection, not all parameters demonstrated such positive correlations. The initial quality of life and performance in the experimental group were higher. However, in patients who had overcome the disease, the

\begin{tabular}{|l|c|c|}
\hline \multicolumn{1}{|c|}{ Parameter/Group } & Experimental & Control \\
\hline Average number of bed-days & 8.74 & 10.76 \\
\hline Average chest CT scans & 1.76 & 50.15 \\
\hline Average age, years & 37.50 & 8.40 \\
\hline Quality of life prior to infection & 9.80 & 6.65 \\
\hline Quality of life after infection & \multicolumn{2}{c|}{9.65} \\
\hline Performance prior to infection & \multicolumn{2}{|c|}{7.50} \\
\hline Performance after infection & 9.10 & 30.00 \\
\hline High blood pressure after discharge, $\%$ & 9.65 & 50.00 \\
\hline Stool problems after discharge, $\%$ & 9.00 & 25.00 \\
\hline Executed therapeutic exercises in the hospital, \% & 0 & 25.00 \\
\hline Executed therapeutic exercises at home after discharge, $\%$ & 0 & \multicolumn{2}{|c|}{} \\
\hline
\end{tabular}

Note: * — по 10-балльной шкале.

Table 2. Patient characteristics: moderate form of the disease $(n=100)$

\begin{tabular}{|c|c|c|}
\hline Parameter/Group & Experimental & Control \\
\hline Average number of bed-days & 12.97 & 14.98 \\
\hline Average chest CT scans & 2.66 & 3.22 \\
\hline Average age, years & 47.10 & 56.74 \\
\hline Quality of life prior to infection* & 9.72 & 8.68 \\
\hline Quality of life after infection* & 8.34 & 7.42 \\
\hline Performance prior to infection ${ }^{\star}$ & 9.82 & 8.47 \\
\hline Performance after infection* & 8.26 & 7.20 \\
\hline High blood pressure after discharge, $\%$ & 7.00 & 17.00 \\
\hline Stool problems after discharge, $\%$ & 5.00 & 13.00 \\
\hline Executed therapeutic exercises in the hospital, \% & 94.00 & 57.00 \\
\hline Executed therapeutic exercises at home after discharge, \% & 94.0 & 66.00 \\
\hline
\end{tabular}

Note: * — по 10-балльной шкале.

Table 3. Patient characteristics: severe form of the disease $(n=24)$

\begin{tabular}{|l|c|c|}
\hline \multicolumn{1}{|c|}{ Parameter/Group } & Experimental & Control \\
\hline Average number of bed-days & 16.40 & 19.10 \\
\hline Average chest CT scans & 4.24 & 5.44 \\
\hline Average age, years & 55.60 & 8.10 \\
\hline Quality of life prior to infection ${ }^{*}$ & 9.15 & 6.80 \\
\hline Quality of life after infection & 6.60 & 8.10 \\
\hline Performance prior to infection & 8.70 & 6.40 \\
\hline Performance after infection* & 5.80 & 0 \\
\hline High blood pressure after discharge, $\%$ & 41.67 & 25.01 \\
\hline Stool problems after discharge, $\%$ & 20.84 & 100.00 \\
\hline Executed therapeutic exercises in the hospital, $\%$ & 62.50 & 62.50 \\
\hline Executed therapeutic exercises at home after discharge, \% & 83.33 & \multicolumn{2}{|c|}{} \\
\hline
\end{tabular}

Note: * — по 10-балльной шкале. 
values of the same parameters appeared to be lower than in control group. Furthermore, more patients in the experimental group reported high blood pressure episodes (41.67\% vs. 0\% in the control group). Meanwhile, the length of stay in a hospital and the number of CT scans were lower in the experimental group. The higher proportion of the experimental group patients practiced therapeutic exercises at home $(83.33 \%$ vs. $62.50 \%$ in the control group), which confirmed the higher initial level of physical activity. However, all control group patients did therapeutic exercises while staying in the hospital (vs. 60.00\% of experimental group patients). That could be due to various comorbidities limiting the therapeutic exercises execution or lack of knowledge about exercise therapy.

\section{CONCLUSION}

Based on the data obtained and the analysis performed, it can be assumed that in patients with more active initial lifestyle, higher performance and better quality of life, the more favourable course of the disease was observed leading to reduced length of stay in a hospital, fast recovery of performance after the SARS CoV-2 infection, and reduced number of CT scans due to milder course of the disease. Such patients with mild and moderate course of the disease reported fewer episodes of high blood pressure after discharge. Moreover, the patients with mild and moderate infection who did therapeutic exercises while staying in the hospital had more favourable outcome and required shorter period of treatment.

All of this confirms the importance of regular physical activity being a proven method of most common noncommunicable diseases prevention. Regarding the current epidemiological situation and the COVID-19 pandemic, it is nesessary to increase awareness about the importance of regular physical exercises and the relationship between physical activity and the novel coronavirus infection prognosis and course generally among elderly people, as well as to introduce the exercise therapy methods both during inpatient treatment and after discharge from hospital.

\section{References}

1. Dogra S., Ashe M.C., Biddle S.J.H., et al. Sedentary time in older men and women: an international consensus statement and research priorities. British journal of sports medicine. 2017; 51: 1526-1532.

2. World Health Organization. Global action plan for the prevention and control of noncommunicable diseases 2013-2020. Geneva: World Health Organization. 2013. Https://apps.who.int/iris/ handle/10665/94384.

3. Nelson M.E., Rejeski W.J., Blair S.N., et al. Physical activity and public health in older adults: recommendation from the American College of Sports Medicine and the American Heart Association. Medicine and science in sports and exercise. 2007; 39(8): 14351445. DOI: $10.1249 / \mathrm{mss} .0 \mathrm{~b} 013 \mathrm{e} 3180616 \mathrm{aa}$.

4. Razavi A.C., Gingras V., Michos E.D., et al. American Heart Association EPI|Lifestyle Scientific Sessions: 2020 Meeting Highlights [published online ahead of print, 2020 Jun 1]. Journal of the American Heart Association. 2020; e017252. DOI: 10.1161/ JAHA.120.017252.

5. Chen P., Mao L., Nassis G.P., Harmer P., Ainsworth B.E., Li F. Coronavirus disease (COVID-19): The need to maintain regular physical activity while taking precautions. Journal of sport and health science. 2020; 9(2): 103-104. DOI: 10.1016/j. jshs.2020.02.001.

6. Jiménez-Pavón D., Carbonell-Baeza A., Lavie C.J. Physical exercise as therapy to fight against the mental and physical consequences of COVID-19 quarantine: Special focus in older people [published online ahead of print, 2020 Mar 24]. Progress in cardiovascular diseases. 2020; S0033-0620(20)30063-3. DOI: 10.1016/j.pcad.2020.03.009.

7. lie P.C., Stefanescu S., Smith, L. The role of vitamin D in the prevention of coronavirus disease 2019 infection and mortality [published online ahead of print, 2020 May 6]. Aging clinical and experimental research. 2020; 1-4. DOI: 10.1007/s40520-020-01570-8.

8. World Health Organization. Global strategy on diet, physical

\section{Литература}

1. Dogra S., Ashe M.C., Biddle S.J.H., et al. Sedentary time in older men and women: an international consensus statement and research priorities. British journal of sports medicine. 2017; 51: 1526-1532.

2. World Health Organization. Global action plan for the prevention and control of noncommunicable diseases 2013-2020. Geneva: World Health Organization. 2013. Https://apps.who.int/iris/ handle/10665/94384.

3. Nelson M.E., Rejeski W.J., Blair S.N., et al. Physical activity and activity and health. Information sheet: global recommendations on physical activity for health 65 years and above. Geneva: World Health Organization. 2011. Https://www.who.int/ dietphysicalactivity/physical-activity-recommendations-65years. pdf?ua $=1$.

9. Wu Z., McGoogan J.M. Characteristics of and important lessons from the coronavirus disease 2019 (COVID-19) outbreak in China: summary of a report of 72314 cases from the Chinese Center for disease control and prevention [published online ahead of print, 2020 Feb 24]. JAMA. 2020;10.1001/jama.2020.2648. DOI: 10.1001/jama.2020.2648.

10. Ministry of Health of Russian Federation. Temporary guidelines: prevention, diagnosis and treatment of new coronavirus infection (COVID-19). Version 7 (03.06.2020) [Temporary guidelines: prevention, diagnosis and treatment of new coronavirus infection(COVID-19). Versiya 7 (03.06.2020)]. Moskva: Ministerstvo zdravookhraneniya Rossiyskoy Federatsii. 2020.] (in Russian)

11. Samoylov A. S., Razinkin S. M., Nazarian S. E, Khan A.V., Shevyakova N. I. Multidisciplinary approach to rehabilitation of athletes of higher achievements. -Questions of balneology, physiotherapy and physical therapy № 2 / / 2016 [Multidisciplinary approach to rehabilitation of athletes of higher achievements. Voprosi kurortologii, fizioterapii i lechebnoi fizkulturi № 2//2016, p. 147] (in Russian).

12. Nazaryan S. E., Petrova M. S., Khan A.V., Smirnova A.V. Experience of combining rehabilitation activities with the precompetition period of the training process on the example of athletics. - Questions of balneology, physiotherapy and physical therapy № 2 / / 2016 [Experience of combining rehabilitation activities with the pre-competition period of the training process on the example of athletics. Voprosi balneologii fizioterapii $i$ lechebnoi fizkulturi. 2//2016, p. 122-123] (in Russian) public health in older adults: recommendation from the American College of Sports Medicine and the American Heart Association. Medicine and science in sports and exercise. 2007; 39(8): 14351445. DOI: $10.1249 / \mathrm{mss} .0 \mathrm{~b} 013 \mathrm{e} 3180616 \mathrm{aa2}$.

4. Razavi A.C., Gingras V., Michos E.D., et al. American Heart Association EPI|Lifestyle Scientific Sessions: 2020 Meeting Highlights [published online ahead of print, 2020 Jun 1]. Journal of the American Heart Association. 2020; e017252. DOI: 10.1161/ 
JAHA.120.017252.

5. Chen P., Mao L., Nassis G.P., Harmer P., Ainsworth B.E., Li F. Coronavirus disease (COVID-19): The need to maintain regular physical activity while taking precautions. Journal of sport and health science. 2020; 9(2): 103-104. DOI: 10.1016/j. jshs.2020.02.001.

6. Jiménez-Pavón D., Carbonell-Baeza A., Lavie C.J. Physical exercise as therapy to fight against the mental and physical consequences of COVID-19 quarantine: Special focus in older people [published online ahead of print, 2020 Mar 24]. Progress in cardiovascular diseases. 2020; S0033-0620(20)30063-3. DOI: 10.1016/j.pcad.2020.03.009.

7. lie P.C., Stefanescu S., Smith, L. The role of vitamin D in the prevention of coronavirus disease 2019 infection and mortality [published online ahead of print, 2020 May 6]. Aging clinical and experimental research. 2020; 1-4. DOI: 10.1007/s40520-02001570-8.

8. World Health Organization. Global strategy on diet, physical activity and health. Information sheet: global recommendations on physical activity for health 65 years and above. Geneva: World Health Organization. 2011. Https://www.who.int/ dietphysicalactivity/physical-activity-recommendations-65years. pdf?ua $=1$.

9. Wu Z., McGoogan J.M. Characteristics of and important lessons from the coronavirus disease 2019 (COVID-19) outbreak in China: summary of a report of 72314 cases from the Chinese Center for disease control and prevention [published online ahead of print, 2020 Feb 24]. JAMA. 2020;10.1001/jama.2020.2648. DOI: 10.1001/jama.2020.2648.

10. Министерство здравоохранения Российской Федерации. Временные методические рекомендации: профилактика, диагностика и лечение новой коронавирусной инфекции (COVID-19). Версия 7 (03.06.2020). Москва: Министерство здравоохранения Российской Федерации. 2020.

11. Самойлов А.С., Разинкин С.М., Назарян С.Е, Хан А.В., Шевякова Н.И. Мультидисциплинарный подход в реабилитации спортсменов высших достижений. - Вопросы курортологии, физиотерапии и лечебной физкультуры № 2 // 2016, C.147.

12. Назарян С.Е., Петрова М.С., Хан А.В., Смирнова А.В. Опыт сочетания реабилитационных мероприятий с предсоревновательным периодом тренировочного процесса на примере легкой атлетики. - Вопросы курортологии, физиотерапии и лечебной физкультуры № 2 //2016, с. 122-123. 